\title{
ADOPTION OF DIGITAL BANKING TECHNOLOGY AND FINANCIAL PERFORMANCE OF COMMERCIAL BANKS IN KENYA
}

\author{
Ouma Stephen Otieno ${ }^{1} \&$ Dr. Fredrick W.S. Ndede ${ }^{2}$ \\ ${ }^{1}$ Correspondent Author, School of Business, Kenyatta University, Kenya \\ ${ }^{2}$ Lecturer, School of Business, Kenyatta University, Kenya
}

ABSTRACT

Commercial banks play a leading role in the economic development of a country and this role of can be achieved only if the banks are stable. Digital banking technology has thus emerged as a way through which the commercial banks can be able to improve their financial performance by enhancing retail and corporate banking activities. From the inception of digital banking, banks have improved their networks in areas of deposits, withdrawals and other banking activities. However, despite the innovative ideas in digital banking, there still exists gaps as some banks still fail and face imminent collapse. The objective of this study was to establish how digital banking technology innovations affects the financial performance of commercial banks. The study took a descriptive survey design and was driven by three objectives namely; determining the effect of access to digital banking technology, turnaround time and digital banking technology costs on financial performance. This study was anchored on financial intermediation theory, innovation diffusion theory and modern economics theory. A questionnaire was used to collect primary data over a target population of 42 commercial banks in Kenya. The study involved a census of the commercial banks in Kenya as at September 2018 and encompassed collection of data through self-administered questionnaires targeting the finance and IT managers of the banks in their headquarters in Nairobi. The data collected was analysed using a descriptive method. The responses were tabulated, coded and processed by use of a computer statistical package for social scientists. The findings of the study were analysed and presented using statistical methods including pie charts and bar graphs and frequency tables. From the findings and summary, the study concluded that the ease of access to digital banking through digital-banking technology innovations had a positive influence on the financial performance of commercial banks in Kenya. The study also concludes that the turnaround time of digital banking technology innovations had a positive impact on the financial performance of commercial banks in Kenya with many of the banking institutions recording high amount of deposits and improved loan values thus creating an opportunity of increasing their customer base.

Key Words: Financial Technology Innovation, Digital Banking Technology, Financial Performance, Turnaround Time, System Downtime

DOI: 10.35942/ijcfa.v2i1.108

\section{Cite this Article:}

Ouma, S., \& Ndede, F. (2020). Adoption of Digital Banking Technology and Financial Performance of Commercial Banks in Kenya. International Journal of Current Aspects in Finance, Banking and Accounting, 2(1), 42-50. https://doi.org/10.35942/ijcfa.v2i1.108 
International Journal of Current Aspects in Finance, Banking and Accounting, Volume 2, Issue 1, 2020 PP 42-50, ISSN 2707-8035

[IJCAB

\section{Introduction}

Digital banking technology through mobile phones is revolutionizing the global banking and payment industry. Digital banking offers millions of people a potential solution in emerging markets that have access to a cell phone, yet remain excluded from the financial mainstream (Kithaka, 2014). Banks have in the recent past shifted from traditional banking to branchless mode of banking since it offers new opportunities for banks to provide added convenience to their existing customers in both developed and developing countries in order to reach a large population of unbanked customers in emerging markets (Mugodo, 2016). Financial performance of commercial banks is critical to the performance of the economy since banks are the main money suppliers for both individuals and institutions. In recent years' banks have developed innovative products and offered a wide range of services in an effort to improve their financial performance which is the ultimate goal of banks. Digital banking has increased provision of financial services with a wider choice of services geared to all levels of society (Bonface, \& Ambrose, 2015).

Banks rely on number of customers and type of banking so as to obtain good return on capital. The performance of banks largely depends on retail and corporate banking activities where the retail customers are widespread in different geographical locations making it a challenge to banks to provide services in such a widespread retail customer. Digital banking established a way in which the banks could address this challenge since brick and mortar system also proved to be expensive. The banking sector in Kenya has seen a steady growth in performance over the recent years from 2011 to 2016. However, during the same period some banks such as National bank in 2015, family bank and housing finance in 2016 registered drops in profitability while others such as Dubai bank, chase bank and imperial bank collapsed (CBK, 2017). This implies that even with the current innovations with regard to mobile and internet banking, banks' performances are still varied with some banks improving their performance while some of the banks have performed dismally and are still facing imminent collapse. The performance variation may be because the banks have not fully embraced the digital banking system and was the core focus of the study.

\section{Research Problem}

Commercial banks have embarked on enhanced digitization putting e-banking on the forefront with a view of improving their network base, reducing personnel costs, competing favorably with their peers and to improve on performance. However, with all this heightened digitization, some banks have shown drop in performance, put under statutory management or closed shops (Mutua, 2013). According to CBK annual report 2015, robust ICT platforms have enabled banks to roll out agency and digital banking services where customers are able to carry out banking services such as deposits and withdrawals from a third party contracted by the bank. Yet, the Business daily analyst in their banking report (2016) warned that the wide shift to non-branch banking carries a risk of lower transactional income, given that these services are cheaper compared to banking hall fees and competition will drive them further down (CBK, 2016). From the available literature, the effects of digital banking on the financial performance of commercial banks in Kenya is not clear as there are scanty documentation available on the issue of digital banking and its effects on the financial performance of commercial banks. In Kenya, how the utilization of digital banking has contributed to the performance or non-performance of these banks is not adequately documented and this study addressed this gap. 
International Journal of Current Aspects in Finance, Banking and Accounting, Volume 2, Issue 1, 2020 PP 42-50, ISSN 2707-8035

[IJCAB

\section{Research Objectives}

The objective of the study was to establish the effects of digital banking technology on the financial performance of commercial banks in Kenya. The specific objectives were:

i. To determine the effect of access to digital banking technology on financial performance of commercial banks in Kenya.

ii. To determine the effects of turnaround time of digital banking technology on financial performance of commercial banks in Kenya.

iii. To establish the effects of costs of adoption and maintenance of digital banking technology on financial performance of banks.

\section{Theoretical Foundation}

\subsection{Financial intermediation theory}

Financial intermediation theory was introduced by Gurley and Shaw in 1960 which they based on the agency theory and theory of informational asymmetry. Financial intermediation is a process which involves surplus units depositing funds with financial institutions who then lend to deficit units (Mutua, 2013). According to Scholtens and Wensveen (2003), the role of the financial intermediary is essentially seen as that of creating specialized financial commodities. For this case, commercial banks acts as financial intermediaries and employs digital banking technology to widen their network to obtain cheaper deposits which they can then lend at a higher interest rate to obtain favorable returns. This theory thus formed an anchor to all the variables for the study.

\subsection{Innovation diffusion theory}

This theory was introduced by Rogers in 1962 to explain how new inventions are diffused among users over a period of time. Diffusion of innovation theory attempts to explain and describe the mechanisms of how new inventions in this case internet and digital banking is adopted and become successful. This theory is an anchor to the first independent and variables which explains access to digital banking as well as the turnaround time of e-banking services. Therefore, the rate of adoption of new innovations will depend on how an organization perceives its relative advantage, compatibility, observability and complexity. Based on this theory, if an organization in Kenya observes the benefits of mobile and internet banking they will adopt these innovations given other factors such as the availability of the required tools.

\subsection{Modern economics theory}

Modem economics theory helps in discovering the various ways through which various expectations and decisions by individuals lead to emergence certain features of communities and societies such as rate of inflation, level of national income, productivity gains, stocks, and prices of various types of capital, cultural values, and social norms (Kithaka, 2014). This theory formed basis or anchor of the third independent variable of the study which is with regard to the cost of digital banking services. The need and expectation of banking customers to be able perform transaction wherever they are and whenever they want, and that of businesses to reduce cost of their operation has influenced digital banking. These needs lead to emergent features as explained by modern economics theory 
International Journal of Current Aspects in Finance, Banking and Accounting, Volume 2, Issue 1, 2020 PP 42-50, ISSN 2707-8035

[IJCAB

\section{Empirical Literature}

According to Aker and Mbithi (2010), there is a strong correlation between mobile phone coverage, the type of services offered, the price of such service, and firm performance. In his study Tchouassi (2012) attempted to find out if mobile phones technology extends banking services to the unbanked persons using empirical Lessons from Selected Sub-Saharan Africa Countries. The study noted that low- income households in Sub-Saharan Africa (SSA) countries lacked access to bank accounts and also faced high costs for performing basic financial transactions. The study thus concludes that mobile phones presented a huge opportunity for the penetration and provision of financial Services to the unbanked population. Wambari (2009) did a case study of digital banking in developing countries using a case of Kenya. This study attempts to find out the importance of digital banking in the daily running of businesses in Kenya and the challenges in using e-banking as a business tool. The study explains that the adoption and use of mobile phones is as a result of a social process which emanates from the social practices of individuals and businesses which leads to some economic benefits.

According to Ritho and Jagongo (2015), Before E-banking was used, and a customer had a lengthy transaction process. The customer would carry her cash to the bank location, make a queue for long at the branch, cash was counted and recorded by the teller in the customer's account. This process made the customers to spend a lot of time in the process besides the great security risk of walking around with cash. An E-banking service enables the customers to deposit money directly from their mobile device to the respective bank accounts. The studies on the turnaround time of Ebanking services have largely focused on the benefits to the customers, however, this study focus on the benefits to the commercial banks and other e-banking service providers. The studies again, do not identify the effect of the turnaround time on the financial performance of commercial banks hence leaving a gap.

Kigen (2010) conducted a study on the impact of digital banking on transaction costs of microfinance institutions. In the study, he established that e-banking had reduced transaction costs significantly even though they were not sensed by the banks because by then there was a small digital banking customer base. Kingoo (2011) considered the relationship between electronic banking and financial performance of commercial banks in Kenya focusing on the microfinance Institutions in Nairobi. The study focused on the wider electronic banking whereas this study will only concentrate on digital banking. This concurs with Munaye (2009) who studied the application of digital banking as a strategic response by equity bank Kenya limited to the challenge in the external environment. Zimmerman (2016) established that digital banking in developing world was an object of skepticism among financial insiders while proponents argued that cell phones could revolutionize personal finance in poorer country, regulators warned of money laundering and most bankers worried that low customer balances wouldn't be worth transaction costs. From the above arguments, this study assumes that digital banking supports the delivery of e-banking services in an organization and the economy.

\section{Conceptual Framework}

The conceptual framework interrelates digital banking and financial performance of commercial banks in Kenya, as indicated in Figure 1. 
International Journal of Current Aspects in Finance, Banking and Accounting, Volume 2, Issue 1, 2020 PP 42-50, ISSN 2707-8035

[IJCAB

Independent variable

Dependent variable

$\begin{aligned} & \text { Access to digital banking } \\ & \text { technology innovations }\end{aligned}$
- $\quad$ Volume of deposits via
digital banking
- Volume of withdrawals
via digital banking
technology
- Volume of loans
disbursed through
- Liquidity position

Turnaround time (TAT) of digital banking technology innovations

- System down time

- Time taken to perform a digital banking technology service

- Time Period of accessing the digital technology platforms

Financial performance:

- Profit after tax (PAT)

\section{Cost of adopting and maintaining digital banking technology innovations}

- Maintenance cost

- User training cost

- Administrative

- Staff cost

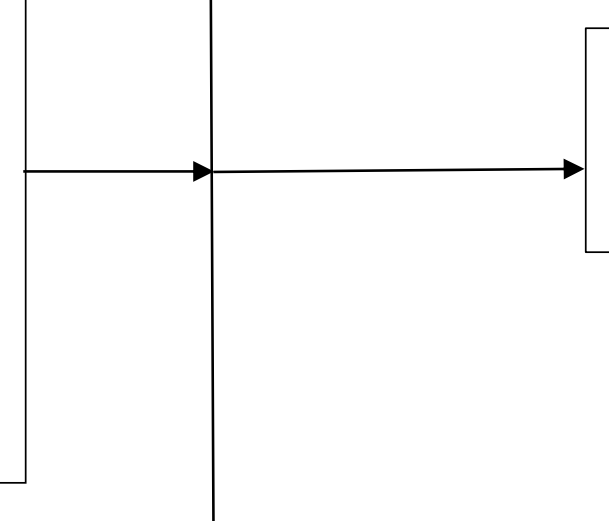

\section{Figure 1: Conceptual Framework}

\section{Research Methodology}

The research adopted descriptive survey research design. The descriptive design was applied because the study involves describing a relationship that exists between a set of variables. The target population was all the 42 commercial banks operating in Kenya according to the central bank supervision report where two respondents from IT and finance department in each bank were 
picked. A census sampling approach was chosen so as to encompass all the 42 commercial banks in 2019. Data was collected using primary means by the use of questionnaires. The collected data was analyzed by means of descriptive and inferential statistics. The data analysis was processed with help of a computer Statistical Package for Social Sciences (SPSS) program. The data was subjected to a regression analysis to measure the relationship between the various digital banking technology and performance of commercial banks. Regression model used for inferential is defined by the regression equation below: $\mathrm{Y}=\alpha+\beta_{1} \mathrm{AM}+\beta_{2} \mathrm{TAT}+\beta_{3} \mathrm{CM}+\dot{\varepsilon}$ Where: $\mathrm{NP}=\mathrm{Net}$ profit of commercial banks, $\alpha=$ Constant term, $\beta_{1}, \beta 2, \beta 3=$ coefficients of determination of independent variables, $\mathrm{AM}=$ access to $\mathrm{m}$-banking services, TAT $=$ Turnaround time of $\mathrm{m}$-banking services and $\mathrm{CM}=$ Costs of M-banking services

\section{Research Findings}

The study found out that all the banks in this study had introduced digital banking services as a result of the financial technology innovations in the industry. The study found that access to digital banking services influenced the financial performance of commercial Banks in Kenya. Further, the study found that he introduction of digital banking technology in the banks improved their key deposits to a great extent while withdrawals levels and value of loan also increased to a great extent. On the other hand, the study found that digital banking technology had improved banks liquidity position moderately. The study also found out that access to financial services through digital banking technology improved financial performance to a moderate extent. This was identified through the growth of customer deposits being supported by mobilization of deposits through agency banking and mobile phone platforms. This study established that most banks experienced system failures while providing the digital banking service. In addition, the study established that the system failures experienced by their banks affect the financial performance of their bank. The study also noted that it was faster to perform transactions through digital banking technology platform than through the banking halls. As a result, most banks introduced the digital banking technology platform because it proved to be an efficient way of tapping into the unbanked population. It was also noted that the system failures and downtime only contributed only to moderate extent to banks losses since most of the losses were recoverable.

This study established that the cost of implementing and maintaining the mobile banking service affects the financial performance of their bank. In addition, the study established that digital banking technology reduced operating cost to a great extent while staff cost, general administrative expense and user training cost reduced to moderate extent. According to Kigen (2010) in regards to a study he has done on the impact of mobile banking on transaction costs of microfinance institutions, he found out that in that period, mobile banking had significantly reduced transaction costs though it did not directly affect the banks because at that time there was a small mobile banking customer base. This was different in that as at the time of this study, the mobile banking customer based had increased significantly.

To determine the relationship between access to digital banking technology, turnaround time when using digital banking technology and the cost of operating a digital banking to financial performance of the commercial banks, a linear regression was carried out. 
International Journal of Current Aspects in Finance, Banking and Accounting, Volume 2, Issue 1, 2020 PP 42-50, ISSN 2707-8035

@ICAB

Table 1: Model Summary

\begin{tabular}{lrrrr}
\hline Model & R & R Square & Adjusted R Square & Std. Error of the Estimate \\
\hline 1 & $.575^{\mathrm{a}}$ & .330 & .166 & .71048 \\
\hline
\end{tabular}

Source: Survey Data (2020)

As shown by Table 1, the coefficient of determination $\mathrm{R}$ square indicates that $33.0 \%$ on the financial performance of the commercial banks in Kenya could be attributed to the changes in access to digital banking technology innovations, turnaround time on digital technology innovations, and cost of adopting and maintenance of digital banking technology all combined.

Table 2: ANOVA results

\begin{tabular}{|c|c|c|c|c|c|}
\hline Model & $\begin{array}{l}\text { Sum of } \\
\text { Squares }\end{array}$ & df & $\begin{array}{c}\text { Mean } \\
\text { Square }\end{array}$ & $\mathbf{F}$ & Sig. \\
\hline 1 Regression & 12.185 & 12 & 1.015 & 2.012 & $.043^{\mathrm{b}}$ \\
\hline Residual & 24.734 & 49 & .505 & & \\
\hline Total & 36.919 & 61 & & & \\
\hline
\end{tabular}

Source: Survey Data (2020)

The ANOVA results for regression coefficients indicate that the significance of the model is 0.043 which is less than 0.05 . The data is therefore ideal for making a conclusion that the independent variables are good predictors of financial performance of commercial banks as supported by a value of significance ( $\mathrm{p}$-value) which is less than 5\% and f statistic of $2.012(2.012, \mathrm{p}<0.05)$.

Table 3: Regression Coefficients

\section{Unstandardized Standardized Coefficients Coefficients}

Std.

\begin{tabular}{llrrrrr} 
Model & & \multicolumn{1}{c}{ B } & Error & Beta & \multicolumn{1}{c}{ T } & Sig. \\
\hline 1 & (Constant) & 2.901 & 1.013 & & 2.864 & .006 \\
& Access & .009 & .141 & .009 & 0.066 & .046 \\
& Turnaround time & .047 & .145 & .028 & 0.137 & .024 \\
& Cost & -.044 & .151 & -.050 & -0.324 & .045 \\
\hline
\end{tabular}

Source: Survey Data (2020)

From the regression model coefficients results obtained, the predictive model thus developed by the study is; $\mathrm{Y}=2.901+0.009 \mathrm{X} 1+0.047 \mathrm{X} 2-0.44 \mathrm{X} 3+\dot{\varepsilon}$. Regression of coefficients results in Table 3 show access to digital banking and financial performance of commercial banks were positively and significantly related $(r=0.009, \mathrm{p}=0.046)$. An increase in the unit change in access to digital banking would lead to increase in financial performance by a factor of 0.009 units. Increased use of digital platforms such as mobile banking would therefore increase financial performance by improving liquidity of the banks.

The results also show that turnaround time and financial performance of commercial banks were positively and significantly related $(\mathrm{r}=0.047, \mathrm{p}=0.024)$. This imply that a unit change in turnaround time (which was measured on how fast a customer completed a mobile transaction, system failures and efficiency). These results support the finding of Olweny and Shipho, (2011), in their study of mobile banking and financial performance where they found that mobile banking enhance performance of commercial banks due to increased efficiency, effectiveness and productivity. 
The results further showed that cost of adopting and maintaining a digital banking technology and financial performance were negatively and significantly related $(\mathrm{r}=-0.044, \mathrm{p}=0.045)$. A unit change in cost adoption and maintenance of digital banking technology innovations would lead to reduction in financial performance by a factor of 0.44 units. The findings were in line with that of Kingoo (2011) who indicated that cost of adopting IT in banking was significantly and negatively related to the bank's profitability and suggested that banks need to manage costs and risks associated with electronic banking while adopting technology to increase their profitability.

\section{Conclusion}

The study concluded that access to digital banking services influenced the financial performance of commercial Banks in Kenya. There was evidence that he introduction of digital banking technology in the banks improved their key deposits to a great extent while withdrawals levels and value of loan also increased to a great extent. The study also concluded that digital banking technology cost affected the financial performance of commercial banks in Kenya moderately. It was noted that digital banking technology reduced operating cost to a great extent while staff cost, general administrative expense and user training cost reduced to moderate extent. Further the study concluded that turnaround time of the digital banking systems affected the financial performance. This study established that most banks experienced system failures while providing the digital banking service which lowered the speed of performing a transaction and in some cases resulted into losses which eventually if not recovered, affect the financial performance of the bank. Additionally, the study concludes that digital banking technology has contributed positively to the financial performance of commercial banks in Kenya. This could be attributed to the trends recorded in the variables where the access to digital platforms by users, reduction in operating cost and improvements in turnaround time had a positive and significant contribution on financial performance of commercial banks in Kenya.

\section{Recommendations}

The study recommends that policy makers consider financial digital technology innovations in their formulation of policies because of the technological developments and the expected switch from traditional brick and mortar system to technologically supported banking services. This is because the impact of such innovations on financial performance could be c higher if there is an increase in innovations. The banks have put in place measures to become more competitive by training its staff, investing in research and development of technology. The study recommends that the financial institutions should offer low transaction rates within their digital networks and ensure deposits of the various customers are protected at all times. This will lure customers to adopt this as a culture thus ensuring the future sustainability of using the digital platforms for banking services. Furthermore, if the its cheaper than the number of people in the remote areas who are unbanked may find it easier to use the banking services. The study recommends that banking institutions should consider coming up with lock in strategies for the already captured market. This will award more power to the bank in controlling the prices and services it offers to its customers. The study recommends that the banking institutions should considered intensifying the M-Banking network which will ensure services accessibility by customers and thus improving financial performance. Finally, the study recommends that commercial banks in Kenya should ensure that systems failures are kept at minimal so as to reduce its influence on the financial performance of commercial banks in Kenya. 
International Journal of Current Aspects in Finance, Banking and Accounting, Volume 2, Issue 1, 2020 PP 42-50, ISSN 2707-8035

[IJCAB

\section{REFERENCES}

Aker, J. C, \& Mbiti, I. (2010). Mobile phones and economic development in Africa. Center for Global Development. 1800 Massachusetts Ave., NW Washington, DC 2003

Bonface, R. M, \& Ambrose, J. (2015). Mobile banking and Financial Performance of Commercial Banks in Kenya. International Journal of Finance and Current Business Studies 4 (12)1631.

Central bank of Kenya (2016). Kenya financial sector stability report: Retrieved from http/www.cbk.co.ke.

Central Bank of Kenya (2017). Banking Sector supervision report. Nairobi; Government of Kenya Printers.

Kigen, M., (2011). Impact of mobile banking on transaction costs of microfinance institutions; A survey of microfinance institutions in Nairobi. Unpublished MBA Thesis, University of Nairobi.

Kingoo, N., (2011). Relationship between electronic banking and financial performance of commercial banks in Kenya. Unpublished MBA Thesis, University of Nairobi.

Kithaka E, (2014). The effect of mobile banking on financial performance of commercial banks. Unpublished MBA Thesis, University of Nairobi.

Mugodo, E. A. (2016). Effect of electronic banking on financial performance of commercial Banks. Unpublished MBA Thesis, University of Nairobi.

Munaye. H. (2009). The application of mobile banking as a strategic response by equity bank Kenya limited to the challenge in the external environment. Unpublished MBA Thesis, University of Nairobi.

Mutua, R. W. (2013). Effect of mobile banking on financial performance of commercial banks. Unpublished MBA Thesis, University of Nairobi.

Olweny, T., \& Shipho, T.M (2011). Effects of banking sectoral factors on the profitability of Commercial banks in Kenya. Economic and Finance Review, 1(5), 1-30.

Scholtens, B. \& Wensveen, D. (2003). The theory of financial intermediation: an essay on what it does (not) explain, SUERF. The European Money and Finance Forum, 5(6),10.

Tchouassi, G. (2012) Can Mobile Phones Really Work to Extend Banking Services to the Unbanked? Empirical Lessons from Selected Sub-Saharan Africa Countries. Development Societies, 1(2),70-81.

Wambari, A. (2009). Mobile banking in Developing Countries (a case study on Kenya). Unpublished Thesis, Vaasan Ammattikorkeakoulu University of applied sciences.

Zimmerman, J. M., (2016). Understanding how consumer risks in digital social payments can erode their financial inclusion potential. International Journal of electronic finance, 2(2) 149 -169

This is an open-access article published and distributed under the terms and conditions of

the cc) $\mathrm{EY}$ Creative Commons Attribution 4.0 International License of United States unless otherwise stated. Access, citation and distribution of this article is allowed with full recognition of the authors and the source.

Authors seeking to publish with an Internationally Peer Reviewed Journals should consider https://www.ijcab.org/ by writing to the Editor at editor@iicab.org or submitting online at https://journals.ijcab.org/journals/index.php. The articles must be quality and meet originality test.

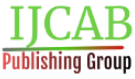

